\title{
Release of Protoplasts from Schizophyllum commune by Combined Action of Purified $\alpha-1,3-$ Glucanase and Chitinase Derived from Trichoderma viride
}

\author{
By O. M. H. DE VRIES AND J. G. H. WESSELS \\ Department of Botany, University of Groningen, Haren, The Netherlands
}

(Received 2I August 1972; revised I8 December 1972)

\begin{abstract}
SUMMAR Y
Protoplast release from young mycelium of Schizophyllum commune by a lytic enzyme preparation from Trichoderma viride was accompanied by degradation of the three wall polymers, S-glucan, R-glucan and chitin. Part of the S-glucan was resistant. The resistance of S-glucan to enzymatic degradation increased with culture age and concomitantly the yield of protoplasts was reduced. Isolated S-glucan was also partly resistant to degradation, probably due to its crystallinity. In living cells S-glucan protected chitin and possibly R-glucan against degradation by external enzymes. S-glucanase, R-glucanase, chitinase and exo-laminarinase were purified from the Trichoderma enzyme mixture. Addition of only S-glucanase and chitinase was essential for protoplast release; R-glucan was degraded endogenously.
\end{abstract}

\section{INTRODUCTION}

In a previous communication (de Vries \& Wessels, I972) it was shown that protoplasts were released from the mycelium of the basidiomycete Schizophyllum commune by an extracellular enzyme preparation of Trichoderma viride grown on hyphal walls of $S$. commune.

The hyphal walls of Schizophyllum commune contain an alkali-insoluble portion consisting of $\beta$-glucan (R-glucan) and chitin (Wessels, I965) and an alkali-soluble $\alpha$-I,3-linked glucan (S-glucan) (Wessels, Kreger, Marchant, Regensburg \& de Vries, 1972). In the present work the degradation of these wall constituents during protoplast release was examined. The results indicate that S-glucanase and chitinase are the essential enzymes in the lytic enzyme preparation.

\section{METHODS}

Organism. Strain 699 of Schizophyllum commune was used throughout.

Lytic enzymes. The enzyme preparation effective in protoplast release was obtained from Trichoderma viride (CBS 354-33, recently renamed as T. harzianum) grown on hyphal walls of Schizophyllum commune as described previously (de Vries \& Wessels, 1972). Other cellwall lytic enzyme preparations were the snail-gut enzymes Helicase (Industrie Biologique Française, Seine, France) and Glusulase (Endo Laboratories, New York, U.S.A.). Chitinases were obtained from Nutritional Biochemicals Corporation (Cleveland, Ohio, U.S.A.) and Koch-Light Laboratories (Colnbrook, Buckinghamshire).

Release of protoplasts. Optimal conditions were derived from previous work (de Vries \& Wessels, 1972) but the mycelium was grown under standing conditions. $\mathrm{MgSO}_{4}(0.5 \mathrm{M})$ 
was used as the osmotic stabilizer in the presence of Na-maleate buffer $(0.05 \mathrm{M})$ at a final $\mathrm{pH} 5.8$, corresponding to an osmotic potential of $-15.8 \mathrm{~atm}$. The ability of enzyme mixtures to release protoplasts was tested in microchambers (de Vries \& Wessels, I972). One-day-old mycelium was used and protoplasts were counted after $\mathrm{I} 5 \mathrm{~h}$ of incubation unless indicated otherwise. When hyphal walls were to be analysed, incubations were carried out in closed tubes at $25^{\circ} \mathrm{C}$ and samples were counted for protoplasts in a haemocytometer.

Preparation of hyphal walls. The mycelium was washed with water and stored at $-30^{\circ} \mathrm{C}$. The walls were disrupted in a cell mill (Vibrogen Zellmühle, Bühler, Germany) with $3 \mathrm{~mm}$ glass beads for $10 \mathrm{~min}$ at full speed. The temperature was maintained at $5{ }^{\circ} \mathrm{C}$. The walls were washed by centrifugation (I0 $\mathrm{min}, 5000 \mathrm{~g}$ ), three times with water, three times with $0.05 \mathrm{M}-\mathrm{Na}$-maleate buffer ( $\mathrm{pH} 5.8$ ) and finally twice with $0.5 \mathrm{M}-\mathrm{MgSO}_{4}$ in $0.05 \mathrm{M}$-Na-maleate buffer (pH 5.8).

Assay of wall components during degradation. The lytic enzyme preparation was incubated with living mycelium or isolated walls, both standardized on the same amount of S-glucan. Incubations were carried out in closed tubes in the presence of $0.5 \mathrm{M}-\mathrm{MgSO}_{4}$ in $0.05 \mathrm{M}-\mathrm{Na}$ maleate buffer ( $\mathrm{pH} 5.8)$ at $25^{\circ} \mathrm{C}$. The reaction was terminated by addition of two volumes of methanol and subsequent heating at $100{ }^{\circ} \mathrm{C}$ for $5 \mathrm{~min}$. All subsequent centrifugations were done at $2000 \mathrm{~g}$ for $10 \mathrm{~min}$. The pellet was washed with $70 \%(\mathrm{v} / \mathrm{v})$ methanol suspended in water and heated at $100{ }^{\circ} \mathrm{C}$ for $20 \mathrm{~min}$. The pellet was washed twice with water, once with methanol and dried at $70^{\circ} \mathrm{C}$.

S-glucan was extracted from the pellet with $2 \mathrm{ml} 5 \% \mathrm{KOH}(\mathrm{w} / \mathrm{v})$ at $60{ }^{\circ} \mathrm{C}$ for $20 \mathrm{~min}$. The residue was washed once with $\mathrm{I} \mathrm{ml} 5 \% \mathrm{KOH}$, once with $2 \mathrm{ml}$ water and S-glucan was precipitated from the combined supernatants by addition of $2 \mathrm{ml} 22.5 \%(\mathrm{v} / \mathrm{v})$ acetic acid. The S-glucan was washed twice with water and dissolved in $2 \mathrm{ml} 5 \% \mathrm{KOH}$.

R-glucan was extracted from the residue in two steps. After a treatment with $3 \mathrm{ml}$ $0.55 \mathrm{~N}-\mathrm{HCl}$ at $100{ }^{\circ} \mathrm{C}$ for $\mathrm{I} \mathrm{h}$ followed by two $2-\mathrm{ml}$ water washings, about $90 \%$ of the R-glucan was found to be present in the combined supernatants. The remaining part was extracted by a subsequent treatment with $3 \mathrm{ml} 5 \% \mathrm{NaOH}$ at $60^{\circ} \mathrm{C}$ for I h followed by two $2 \mathrm{ml}$ water washings. All glucan fractions were brought to $10 \mathrm{ml}$ with water and the glucan content was determined with the anthrone reagent (Fairbairn, 1953). Chitin was assayed by hydrolysis of the glucan-extracted residue in $3 \mathrm{ml} 6 \mathrm{~N}-\mathrm{HCl}$ at $100{ }^{\circ} \mathrm{C}$ for $6 \mathrm{~h}$ and determination of the glucosamine in the hydrolysate (Roseman \& Daffner, I956).

Separation of enzymes. CM-cellulose (Serva Entwicklungslaber, Heidelberg, Germany) was prepared for use according to Peterson (1970) and equilibrated with 0.0I M-Na-acetate buffer $(\mathrm{pH} 3.8)$. The column $(27 \times \mathrm{I} \cdot 25 \mathrm{~cm})$ was packed and eluted at a flow rate of $60 \mathrm{ml} / \mathrm{h}$. After elution of unbound protein (absorbance at $280 \mathrm{~nm}$ ) a linear gradient of $\mathrm{NaCl}$ from

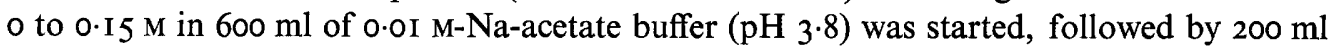
of $\mathrm{O} \cdot \mathrm{I} \mathrm{M}-\mathrm{Na}$-acetate buffer containing $\mathrm{O} \cdot \mathrm{I} \mathrm{M}-\mathrm{NaCl}$ with a $\mathrm{pH}$ gradient from 4.0 to 5.5 . Fractions of $4 \mathrm{ml}$ were collected. Salt concentrations were determined by measuring conductivities.

Sephadex G-I00 (Pharmacia Fine Chemicals AB, Uppsala, Sweden) was equilibrated with $0.05 \mathrm{M}-\mathrm{Na}$-acetate buffer $(\mathrm{pH} 5 \cdot 2)$. The column $(98 \times \mathbf{I} \cdot 20 \mathrm{~cm})$ was eluted with the same buffer at a flow rate of $8 \mathrm{ml} / \mathrm{h}$. Fractions of $2 \mathrm{ml}$ were collected.

Chitinase was selectively removed from enzyme mixtures by adsorption on acid-swollen chitin and subsequently recovered after digestion of the chitin according to Jeauniaux (I966). To remove $98 \%$ of the chitinase five adsorption cycles were necessary. Only the chitinase adsorbed in the first two cycles was recovered.

Enzymes in pooled fractions were precipitated by addition of ammonium sulphate 

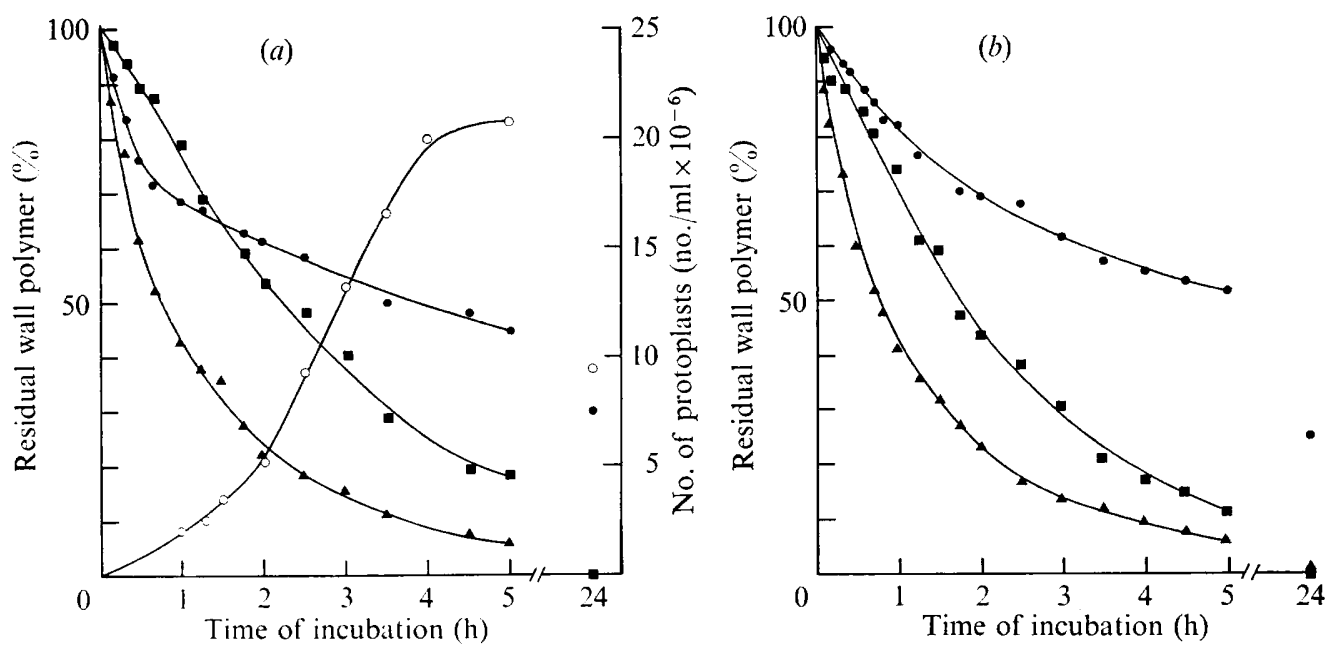

Fig. I. Degradation of polymers of the hyphal wall of Schizophyllum commune by Trichoderma enzymes $(0.25 \mathrm{mg}$ protein $/ \mathrm{ml})$. (a) Living mycelium $(5.8 \mathrm{mg}$ dry $\mathrm{wt} / \mathrm{ml}$; culture age, 2 days). (b) Hyphal walls, derived from the same culture and standardized on the same amount of S-glucan ( $\cdot \circ \mathrm{mg}$ glucose equivalents $/ \mathrm{ml}$ ). $\bigcirc$, Protoplasts; $O$, S-glucan; $\boldsymbol{\Delta}$, R-glucan; $\boldsymbol{\square}$, chitin.

( $75 \%$ saturation). After standing overnight the precipitates were collected, dialysed against water, lyophilized and finally taken up in $250 \mu \mathrm{l}$ water.

Enzyme activities. Enzyme activities towards S-glucan, R-glucan, laminarin and chitin were determined as described earlier (de Vries \& Wessels, 1972) except for the buffer used. Enzyme activities in column fractions were determined in the presence of $0.1 \mathrm{M}$-Na-acetate buffer $(\mathrm{pH} 5 \cdot 2)$ by measuring the increase in reducing power only. In all other instances $0.05 \mathrm{M}-\mathrm{Na}$-maleate buffer ( $\mathrm{pH} 5.8$ ) was used.

Because one of the isolated chitinases did not release $\mathbf{N}$-acetylglucosamine despite the addition of $\beta$-glucosidase (Sigma Chemical Company, St Louis, Missouri, U.S.A.), the incubation mixture was centrifuged (Io $\mathrm{min}, 20000 \mathrm{~g}$ ) and the supernatant, containing the hydrolysis products, was re-incubated with crude Trichoderma enzymes $(0.25 \mathrm{mg}$ protein $/ \mathrm{ml})$ at $30{ }^{\circ} \mathrm{C}$ for $2 \mathrm{~h}$ in a total volume of $\mathrm{I} \mathrm{ml}$ buffer and then assayed for $\mathrm{N}$-acetylglucosamine (Reissig, Strominger \& Leloir, 1955).

Reducing power was measured with the neocuproine reagent (Dygerts, Li, Florida \& Thoma, I 965), glucose with the Glucostat reagent (Worthington Biochemical Corporation, Freehold, New Jersey, U.S.A.) and protein by the method of Lowry, Rosebrough, Farr \& Randall (I95I) with bovine albumin (Sigma Chemical Company) as a standard.

\section{RESULTS}

Degradation of wall polymers in living mycelium and isolated hyphal walls by lytic enzymes

Fig. I $(a)$ shows that protoplast release by Trichoderma enzymes was accompanied by degradation of R-glucan, S-glucan and chitin. After $40 \mathrm{~min}$, when the first protoplasts appeared, about $50 \%$ of the R-glucan, $30 \%$ of the S-glucan and $15 \%$ of the chitin were digested. After this time the rate of degradation of S-glucan was much slower. After $5 \mathrm{~h}$, when the maximal number of protoplasts was released, R-glucan as well as chitin were largely degraded but about half of the S-glucan was still present. Even after $24 \mathrm{~h} 30 \%$ of 
Table I. Comparison of degradation of wall polymers in living cells and in isolated hyphal walls of Schizophyllum commune by lytic enzyme preparations

\begin{tabular}{lcccccc}
\multicolumn{4}{c}{ Living cells } & & \multicolumn{3}{c}{ Cell walls } \\
Lytic enzymes & $\overbrace{\text { S-glucan }}^{\text {Degradation of cell wall component* }(\%)}$ \\
$\begin{array}{l}\text { None } \\
\text { Trichoderma enzymes }\end{array}$ & 0 & 38 & 0 & 0 & 0 & Chitin \\
Helicase & 52 & 94 & 79 & 56 & 96 & 90 \\
S-glucan & R-glucan & Chitin \\
S-glucan & 0 & 42 & 4 & 0 & 43 & 24
\end{tabular}

* Living mycelium $(6.5 \mathrm{mg}$ dry $\mathrm{wt} / \mathrm{ml}$; culture age, 2 days) and hyphal walls isolated from the same culture $(2.4 \mathrm{mg}$ dry wt/ml), standardized on the same amount of S-glucan $(0.85 \mathrm{mg}$ glucose equivalents $/ \mathrm{ml})$, were suspended in $0.5 \mathrm{M}-\mathrm{MgSO}_{4}, 0.05 \mathrm{M}-\mathrm{Na}$-maleate buffer $\left(\mathrm{pH}_{5} .8\right)$ and incubated with lytic enzymes for $5 \mathrm{~h}$ at $25^{\circ} \mathrm{C}$. Concentrations of lytic enzymes were: Trichoderma enzymes, $0.8 \mathrm{mg}$ protein/ml; Helicase, $5.3 \mathrm{mg}$ protein/ml. The data are mean values of four determinations.

the S-glucan originally present was not broken down, maintaining a recognizable hyphal morphology. However, walls appeared much thinner and septa had disappeared except for ring-shaped basal thickenings.

Fig. I $(b)$ shows the degradation curves of the wall polymers in isolated hyphal walls, derived from the same culture, under identical conditions. The wall preparation, standardized on the same amount of S-glucan, also contained the same amount of chitin. However, the R-glucan content was $34 \%$ lower, possibly indicating that part of the R-glucan analysed in Fig. I $(a)$ did not belong to the wall proper. Comparison of the curves in Fig. I $(a)$ and $(b)$ reveals that the rates of breakdown of the three wall polymers in living mycelium and isolated walls were generally similar. Thus, these results do not give evidence for a difference in the accessibility to enzymes of the wall polymers in living mycelium and isolated walls.

A difference in accessibility could be demonstrated by using a snail-enzyme preparation. The snail-enzyme preparations are unable to degrade S-glucan or to release protoplasts from Schizophyllum commune (de Vries \& Wessels, I972). Table I shows that the snailenzyme preparation did degrade chitin in isolated walls but hardly in living mycelium. For R-glucan the results were less clear because in the living mycelium, but not in isolated walls, there was a breakdown of alkali-insoluble glucan (R-glucan) in the control, without enzymes added. Addition of snail-enzymes hardly increased this breakdown but in isolated walls the enzymes were quite effective in degradation of R-glucan. These results indicate that in living cells S-glucan protects chitin and possibly R-glucan against external enzymatic attack.

\section{Protoplast release and degradation of wall polymers in relation to culture age}

It was shown earlier that the age of the mycelium strongly affects the yield of protoplasts (de Vries \& Wessels, I972). The effectiveness of Trichoderma enzymes in degrading the three wall polymers, S-glucan, R-glucan and chitin, in mycelia of different culture age was determined. The results are depicted in Fig. 2. The amount of S-glucan/mg wet weight mycelium remained virtually the same during the 6-day growth period but the S-glucan/Rglucan and S-glucan/chitin ratios decreased after 3 days of growth and concomitantly the yield of protoplasts was greatly reduced. Irrespective of the culture age, however, both $\mathrm{R}$-glucan and chitin were digested almost completely during the $5 \mathrm{~h}$ of incubation with Trichoderma enzymes. Only the S-glucan fraction was degraded less effectively after the 

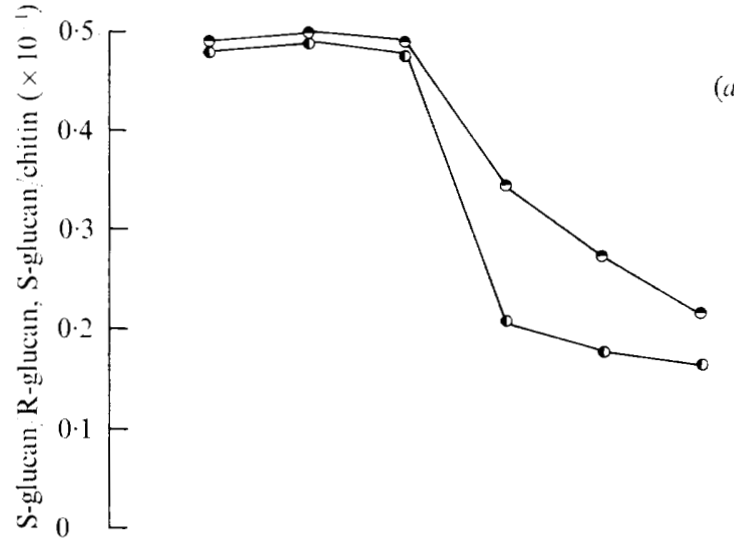

(a)

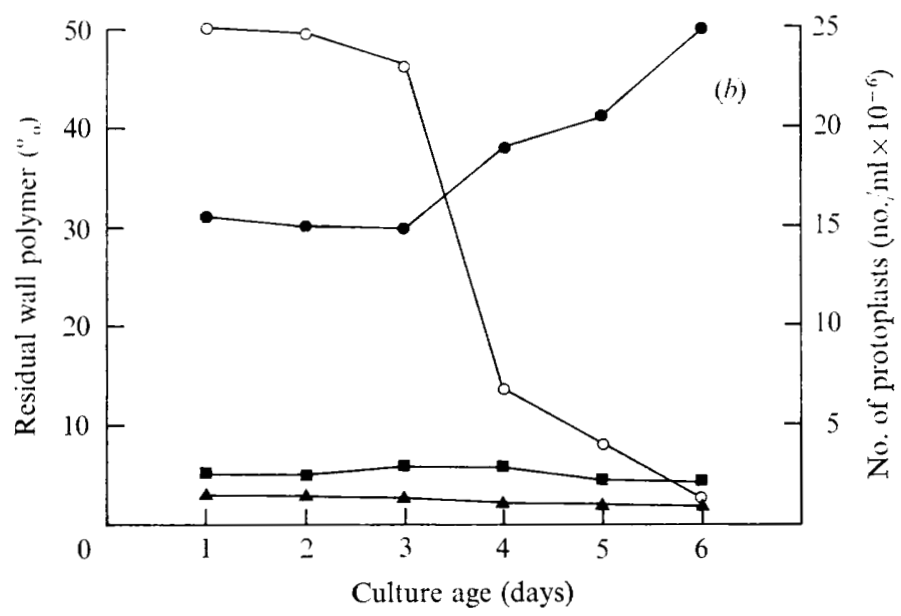

Fig. 2. (a) Ratios of the polymers of the hyphal wall in mycelia of Schizophyllum commune at different culture age. (b) Protoplasts release and degradation of the wall polymers in the same mycelia by Trichoderma enzymes $(25 \mathrm{mg}$ wet wt mycelium $/ \mathrm{ml} ; 0.54 \pm 0.04 \mathrm{mg}$ glucose equivalents S-glucan/ml; $1.25 \mathrm{mg}$ protein enzyme/ml; $5 \mathrm{~h}$ of incubation). $\theta$, S-glucan/R-glucan ratio; $\boldsymbol{O}$, S-glucan/chitin ratio; O, protoplasts; $\bullet$, S-glucan; $\mathbf{\Delta}$, R-glucan; $\mathbf{E}$, chitin.

culture age exceeded 3 days and the amount remaining after enzyme action increased from 30 to $50 \%$. Thus, the degree of S-glucan breakdown was correlated with the number of protoplasts released.

The influence of the physical state of isolated S-glucan on its enzymatic degradation

Isolated S-glucan, precipitated from alkaline solution by acid (Wessels, 1965), and suspended in buffer $(0.2 \%$ in $0.05 \mathrm{M}-\mathrm{Na}$-maleate buffer, $\mathrm{pH} 5.8)$ could be degraded only about $40 \%$ by the Trichoderma enzyme preparation (I mg protein/ml, 24 hours of incubation at $30^{\circ} \mathrm{C}$ ). Reincubation of the residue with fresh enzymes did not effect further degradation. However, by using S-glucan precipitated from alkaline solution with two volumes of ethanol $(96 \%, \mathrm{v} / \mathrm{v})$ more than $70 \%$ of the S-glucan was degraded under the same conditions. S-glucan could be completely degraded by a three times repeated procedure in which incubation with Trichoderma enzymes $(2 \mathrm{~h})$ was followed by dissolution in alkali and reprecipitation with ethanol of the residual S-glucan. This indicates that the physical state of isolated S-glucan determined its resistance towards enzymatic attack. 


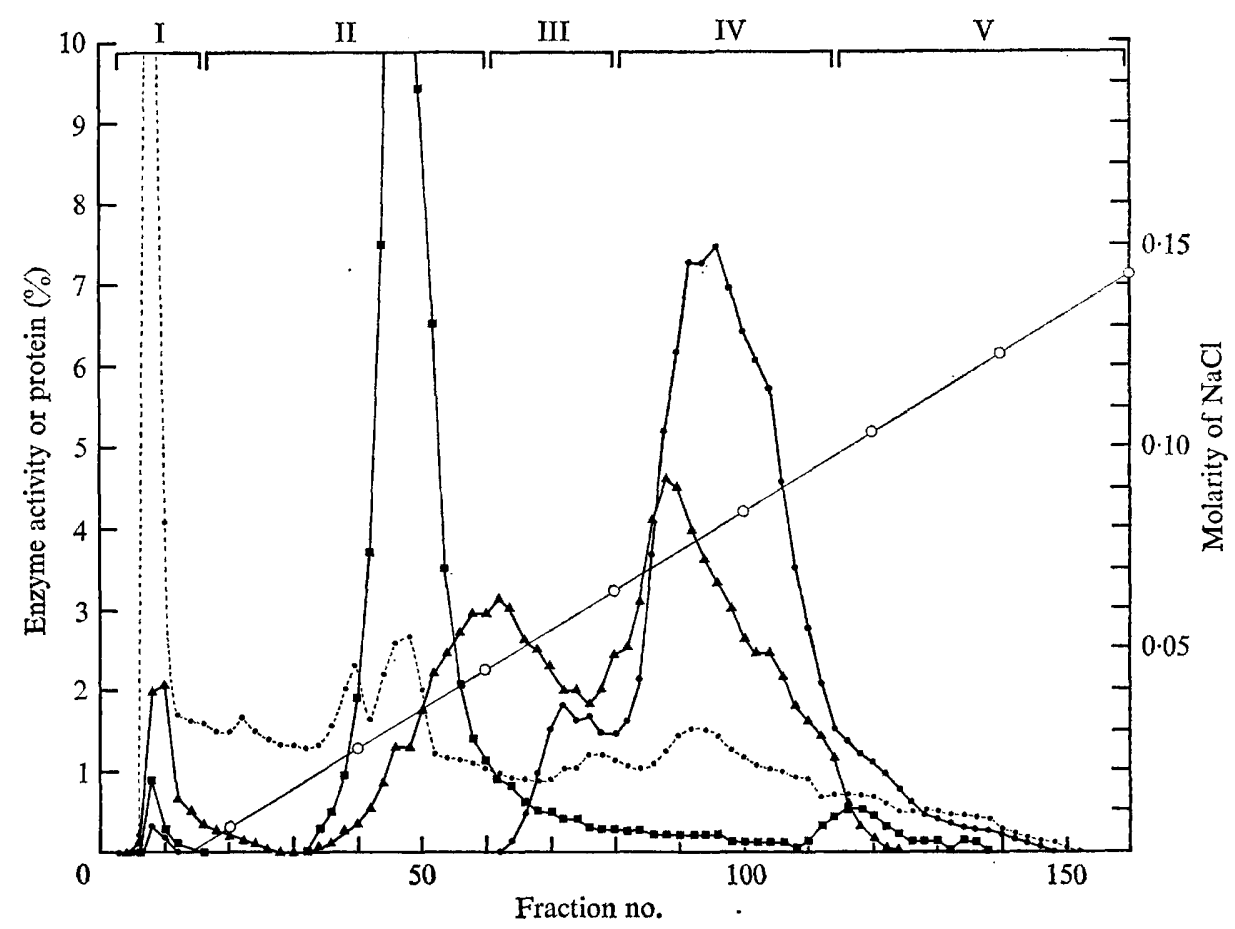

Fig. 3. Fractionation of Trichoderma enzymes (I2.5 $\mathrm{mg}$ protein) on CM-cellulose. Enzyme fractions I-V were obtained by pooling fractions as indicated and reduced to $250 \mu$ l. Activity is expressed as a percentage of the total eluted activity. For details see text. - , S-glucanase;

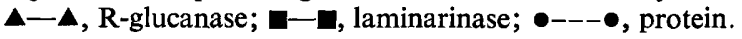

Table 2. Enzyme activities in various fractions obtained after CM-cellulose chromatography of Trichoderma enzymes

\begin{tabular}{|c|c|c|c|c|}
\hline \multirow[b]{2}{*}{ Fraction $\dagger$} & \multicolumn{4}{|c|}{ Enzyme activity* } \\
\hline & Laminarinase & R-glucanase & S-glucanase & Chitinase \\
\hline I & $1 \cdot 8$ & $4 \cdot 3$ & 0.0 & $3 \cdot I$ \\
\hline II & 85.8 & 17.0 & 0.0 & 5.9 \\
\hline III & $6 \cdot 2$ & $26 \cdot 4$ & $5 \cdot 6$ & $24 \cdot 8$ \\
\hline IV & 47 & $40 \cdot 9$ & $92 \cdot 8$ & $27 \cdot 5$ \\
\hline V & $I \cdot 5$ & II $\cdot 3$ & $I \cdot 6$ & $9 \cdot 9$ \\
\hline VI & 0.0 & 0.1 & 0.0 & $28 \cdot 8$ \\
\hline
\end{tabular}

* The enzyme activity in each fraction is given as a percentage of the total activity. $\uparrow$ See Fig. 3 and text.

Fractionation of Trichoderma enzymes and identification of enzymes active in protoplast release

A number of activities of the Trichoderma enzymes towards various polysaccharides were listed earlier (de Vries \& Wessels, I972). In order to identify crucial protoplastreleasing enzymes the Trichoderma enzyme mixture was fractionated according to activities towards laminarin, S-glucan, chitin and R-glucan.

Separation of laminarinase and S-glucanase was achieved by CM-cellulose column chromatography at relative low $\mathrm{pH}$ and low ionic-strength (Fig. 3). Fractions were pooled as indicated and the volumes were reduced to $250 \mu \mathrm{l}$ (Fractions I-V). In addition, a fairly 


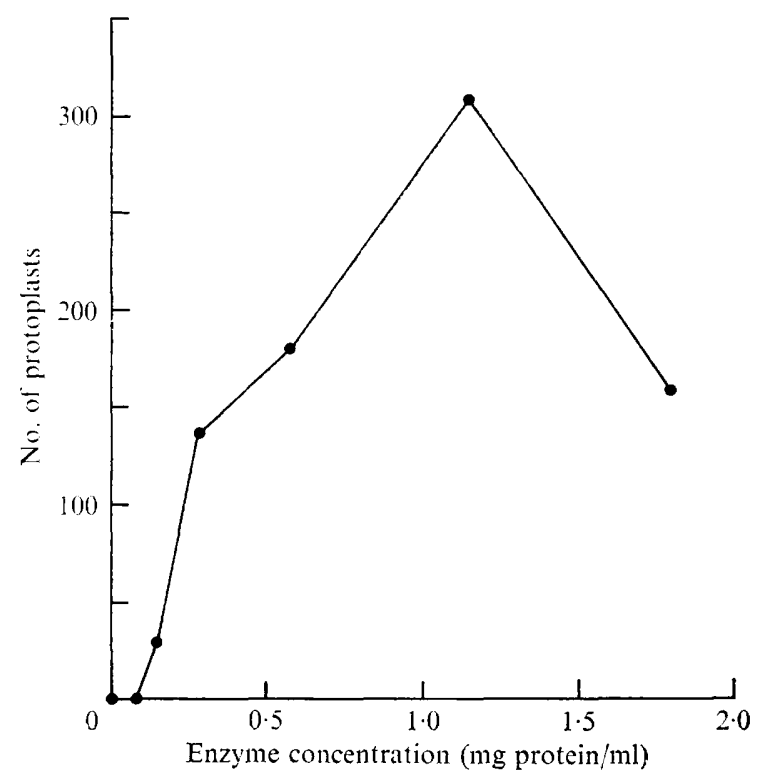

Fig. 4. Effect of the concentration of recombined Trichoderma enzymes on protoplast release in Schizophyllum commune. The recombined enzyme preparation was obtained by combining equal volumes of the enzyme fractions I to VI described in Table 2.

Table 3. Effect of various enzyme fractions obtained from a Trichoderma enzyme preparation on protoplast release in Schizophyllum commune

\begin{tabular}{ccccccc}
\multicolumn{9}{c}{ Fraction* } \\
I & II & III & IV & V & VI & $\begin{array}{c}\text { No of } \\
\text { protoplasts }\end{array}$ \\
+ & + & + & + & + & + & 89 \\
- & + & + & + & + & + & 85 \\
- & - & + & + & + & + & 80 \\
- & - & - & + & + & + & 64 \\
- & - & - & - & + & + & 0 \\
- & - & - & - & - & + & 0 \\
- & - & - & + & - & + & 62 \\
- & - & - & + & - & - & 5
\end{tabular}

* The fractions refer to the enzyme fractions described in Table 2.

pure chitinase was eluted by subsequently using a $\mathrm{pH}$ gradient (fraction VI, eluted between $\mathrm{pH} 4.0$ and $4 \cdot 8$ ).

Table 2 lists the enzyme activities in the various enzyme fractions obtained. The laminarinase, almost all of which was present in fraction II, most probably was an exo- $\beta$-I, 3glucanase, because even after short incubation periods all the released reducing power could be accounted for by released glucose. Apart from a small amount of S-glucanase in fraction III, representing a minor peak, most of the S-glucanase was present in fraction IV. R-glucanase activity was eluted as two peaks, the first one present in fractions II and III while the second was mainly present in fraction IV. Two kinds of chitinase activity were detected. In contrast to the chitinase in fraction VI (chitinase II), the chitinase in other fractions (chitinase I) did not release a measurable amount of reducing groups or $\mathrm{N}$-acetylglucosamine 


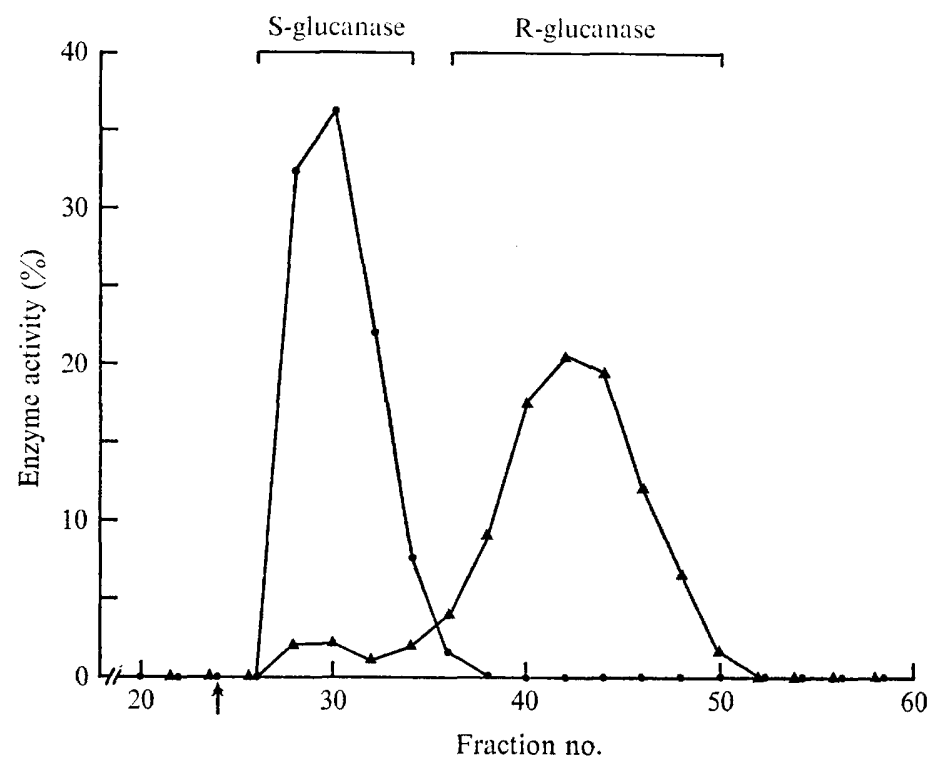

Fig. 5. Fractionation of enzyme fraction IV from Trichoderma viride (Table 2) after removal of chitinase on Sephadex G-100. The void volume corresponds to fraction 24. S-glucanase and R-glucanase preparations were obtained by pooling fractions as indicated and reduction of the volumes to $250 \mu \mathrm{l}$. Activity is expressed as a percentage of the total eluted activity. For details see text. - - S-glucanase; $\boldsymbol{\Delta}-\boldsymbol{\Delta}$, R-glucanase.

Table 4. Effectiveness of various purified enzyme preparations in releasing protoplasts from Schizophyllum commune

\begin{tabular}{ccccc}
\multicolumn{9}{c}{ Enzyme preparation* } & No of \\
R-glucanase & Chitinase I & Chitinase II & S-glucanase & $\begin{array}{c}\text { Notoplasts } \\
\text { proto }\end{array}$ \\
+ & + & + & + & II6 \\
+ & + & + & - & 0 \\
- & + & + & + & I I0 \\
- & - & + & + & 107 \\
- & + & - & + & 20 \\
- & - & - & + & 0
\end{tabular}

* The enzyme preparations were obtained after purification of the crude Trichoderma enzymes (see text).

from chitin and the activity could only be detected after further digestion of solubilized products by the crude Trichoderma enzyme preparation.

A combination of equal volumes of the fractions I to VI yielded an enzyme mixture competent in releasing protoplasts from Schizophyllum commune. Fig. 4 shows the effect of varying the concentration of this preparation on the release of protoplasts. A concentration of $0.5 \mathrm{mg}$ protein $/ \mathrm{ml}$ was selected for studying the effect of omission of individual fractions from the complete mixture. The results of such an analysis are presented in Table 3 . Fractions I and II did not affect protoplast release, thus excluding the exo-laminarinase as a necessary enzyme. Omission of fraction III alone or in combination with fraction $\mathrm{V}$ only slightly affected the protoplast releasing activity. However, both fractions IV and VI were essential. The fact that in fraction VI only chitinase (chitinase II) could be demonstrated suggests that this enzyme was the effective component. On the other hand, 


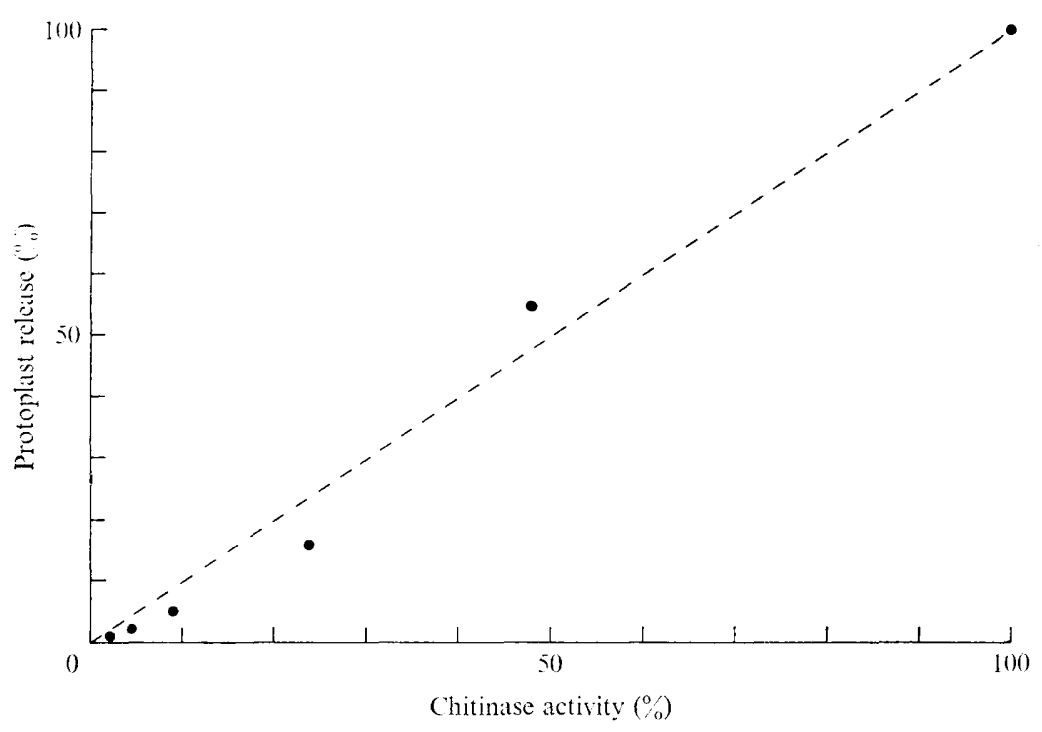

Fig. 6. Effect of reduction of the chitinase activity in the Trichoderma enzyme preparation on protoplast release in Schizophyllum commune. The reductions in chitinase resulted from successive treatments of the Trichoderma enzyme preparation ( $\mathrm{mg}$ protein/ml) with acid-swollen chitin ( $\mathrm{mg}$ dry wt/ml). Protoplasts were counted after $5 \mathrm{~h}$ of incubation.

Table 5. Effect of removed and recovered chitinase from a crude Trichoderma enzyme preparation on protoplast release in Schizophyllum commune

\begin{tabular}{|c|c|c|c|c|c|}
\hline \multirow[b]{2}{*}{ Enzyme preparation } & \multicolumn{4}{|c|}{ Enzyme activity* } & \multirow{2}{*}{$\begin{array}{l}\text { No of } \\
\text { protoplasts }\end{array}$} \\
\hline & Laminarinase & R-glucanase & S-glucanase & Chitinase & \\
\hline Crude & 100 & 100 & 100 & 100 & 107 \\
\hline Chitinase removed & 67 & $5 \mathrm{l}$ & 75 & 2 & I \\
\hline Recovered chitinase & 5 & I I & 4 & 120 & 8 \\
\hline Combination $2+3$ & - & 一 & - & - & 140 \\
\hline
\end{tabular}

* Concentration of the crude Trichoderma enzyme preparation was $1 \mathrm{mg}$ protein/ml and protoplasts were counted after $5 \mathrm{~h}$. Activities are given as percentage of the activities present in the crude enzyme preparation.

fraction IV contained S-glucanase, R-glucanase and chitinase (chitinase II) as well (Table 2).

Fraction IV, used at to times higher concentration, was the only fraction competent to release normal protoplasts when tested individually, although fraction III induced the liberation of a few empty-looking small vesicles. The capacity of fraction IV to release protoplasts was completely lost after removal of the chitinase by adsorption on colloidal chitin. The chitinase was recovered (chitinase 1) and S-glucanase and R-glucanase in the chitinase-free fraction IV were separated by Sephadex G-I00 gel filtration (Fig. 5). Fractions were pooled as indicated and concentrated $(250 \mu 1)$.

The effectiveness of the various purified enzyme preparations, alone and in combinations, in releasing protoplasts was analysed. Some crucial results are listed in Table 4. Apparently, a combination of S-glucanase and a chitinase is the only requirement for protoplast release. Addition of R-glucanase is not necessary. 


\section{Protoplast release by combined action of S-glucanase and snail enzymes}

Helicase and Glusulase (final concentration 4.3 and $15.0 \mathrm{mg}$ protein $/ \mathrm{ml}$, respectively) were ineffective in releasing protoplasts. When supplemented with the S-glucanase, R-glucanase and chitinase (I and II) preparations in all combinations, only those supplemented with S-glucanase showed protoplast-releasing activity. When the S-glucanase preparation was boiled for $5 \mathrm{~min}$ its capacity to confer protoplast releasing activity to Helicase and Glusulase was completely lost.

\section{Effect of reduction of chitinase activity in Trichoderma enzymes on protoplast release}

Five successive treatments with acid-swollen chitin removed $98 \%$ of the chitinase activity from a crude Trichoderma enzyme preparation. Each treatment, which resulted in $50 \%$ decrease of the chitinase activity, was accompanied by approximately $50 \%$ reduction of the protoplast releasing activity as shown in Fig. 6. It was demonstrated that the removal of chitinase was selective and that the ability of the chitinase-deficient enzyme mixture to release protoplasts was restored by supplementation with the recovered chitinase (Table 5). The latter preparation also could be replaced by commercially obtained chitinase preparations, which alone were ineffective in releasing protoplasts.

\section{DISCUSSION}

Protoplasts have been obtained from fungi belonging to all the major taxonomic groups (cf. Villanueva \& Garcia Acha, I97I). However, in the basidiomycetes, protoplast release has only been reported in Polystictus versicolor (Strunk, 1969) and Schizophyllum commune (de Vries \& Wessels, 1972). Only in the latter species has knowledge about the nature of the wall constituents (Wessels, I965; Wessels et al. 1972) proceeded so far that a study on the enzymes involved in protoplast release could be pursued.

Although the three major hyphal-wall components, chitin, R-glucan ( $\beta$-I,3, $\beta$-I,6-glucan) and S-glucan ( $\alpha$-I,3-glucan) were all degraded during protoplast release it appeared that only S-glucanase and chitinase were the essential components of the Trichoderma lytic system. The ineffectiveness of exo-laminarinase, an enzyme which has been shown to be involved in protoplast release in several fungi (Sietsma, Eveleigh \& Haskins, 1969; Bastide, Trave \& Bastide, 197I ; Bauer, Bush \& Horisberger, 1972), is in accordance with the finding that $\mathrm{R}$-glucan is quite resistant to $\beta$-I,3-glucanases when compared with yeast-glucan (Wessels, I969). Surprisingly, glucanases which did degrade R-glucan were also nonstimulatory. Since degradation of R-glucan was observed even without enzymes added, the possibility remains that autolytic degradation did occur. The necessity of addition of chitinase has been demonstrated in other work too (Domanski \& Miller, 1968; Sietsma \& Wouters, 197I), but this appears the first instance in which an essential role for $\alpha$-I,3glucanase has been shown.

The evidence that S-glucanase, and not some unknown enzyme activity in the enzyme preparation, was effective is strengthened by the fact that this preparation was also active in combination with snail-gut digestive enzyme preparations which have been shown to contain some 30 or more different hydrolases (Holden \& Tracey, I950) but no S-glucanase (Kanetsuna, Carbonell, Moreno \& Rodriguez, I969; de Vries \& Wessels, 1972).

The comparison of the breakdown of wall components in living mycelium and isolated hyphal walls by snail enzymes suggests that chitin is protected from enzymatic attack by a covering S-glucan layer. This is in accordance with the reported localization of this glucan 
at the surface of the hyphae (Hunsley \& Burnett, 1970; Wessels et al. 1972). It has been shown that at least part of this glucan in situ and after isolation is characterized by a microcrystalline condition displaying a typical rodlet structure (Wessels et al. 1972). The fact that S-glucanase only degraded part of this glucan in the hyphal wall may be due to resistance of the crystalline part of S-glucan to S-glucanase. This is indicated by the fact that acidprecipitated isolated S-glucan, which also shows crystallinity (Wessels et al. 1972), reacted to S-glucanase as did the S-glucan in the wall. The resistant fraction, however, disappeared when the glucan was precipitated with ethanol. It is likely that ethanol inhibited the formation of crystal lattices during precipitation.

The results show that the decrease in ability to produce protoplasts with ageing of the mycelium was correlated with a decrease in the susceptibility of S-glucan to enzymatic degradation. If crystallinity is a factor determining the susceptibility of S-glucan to enzymatic attack, this suggests that the decrease of protoplast release with increasing culture age is due to an increase in crystallinity of S-glucan. However, the possibility that other agedependent factors are involved cannot be excluded.

We acknowledge the technical assistance of Miss H. C. J. Viersma.

\section{REFERENCES}

Bastide, J. M., Trave, P. \& Bastide, M. (I971). Étude de la paroi cellulaire de Candida macedoniensis: formation de protoplastes. Annales de l'Institut Pasteur r21, 31 I-324.

Bauer, H., Bush, D. A. \& Horisberger, M. (1972). Use of the exo- $\beta$-I,3-glucanase from Basidiomycete QM 806 in studies on yeast. Experientia 28, I I-I3.

DomANSki, R. E. \& Miller, R. E. (I968). Use of a chitinase complex and $\beta$-I,3-glucanase for spheroplast production from Candida albicans. Journal of Bacteriology 96, 270-27I.

Dygerts, S., Li, L. H., Florida, D. \& Thoma, J. A. (I965). Determination of reducing sugar with improved precision. Analytical Biochemistry 13, 367-374.

FaIrbairn, N. J. (1953). A modified anthrone reagent. Chemistry \& Industry, 86.

Holden, M. \& TraCEY, M. V. (1950). A study of enzymes that can break down tobacco-leaf components. Biochemical Journal 47, 407-4I4.

Hunsley, D. \& BurnetT, J. H. (1970). The ultrastructural architecture of the walls of some hyphal fungi. Journal of General Microbiology 62, 203-2 18.

JeauniauX, C. (1966). In Methods in Enzymology, vol viIr, pp. 644-650. Edited by E. F. Neufeld and V. Ginsburg. New York: Academic Press.

Kanetsuna, F., Carbonell, L. M., Moreno, R. E. \& Rodriguez, J. (I969). Cell wall composition of the yeast and mycelial forms of Paracoccidioides brasiliensis. Journal of Bacteriology 97, 1037-I04I.

Lowry, O. H., Rosebrough, N. J., Farr, A. L. \& Randall, R. J. (I95I). Protein measurement with the Folin phenol reagent. Journal of Biological Chemistry $193,265-275$.

Peterson, E. A. (1970). Cellulosic ion exchangers. In Laboratory Techniques in Biochemistry and Molecular Biology, vol. 2, pp. 228-397. Edited by T. S. Work and E. Work. Amsterdam: North-Holland Publishing Company.

Reissig, J. L., Strominger, J. L. \& Leloir, L. F. (1955). A modified colorimetric method for the estimation of N-acetyl aminosugars. Journal of Biological Chemistry 217, 959-966.

Roseman, S. \& DAFFner, I. (1956). Colorimetric method for the determination of glucosamine and galactosamine. Analytical Chemistry 28, I743-I 746.

Sietsma, J. H., Eveleigh, D. E. \& Haskins, R. H. (I969). Cell wall composition and protoplast formation of some oomycete species. Biochimica et biophysica acta 184, 306-317.

Sietsma, J. H. \& Wouters, J. T. M. (I97I). Cell wall composition and 'protoplast' formation of Geotrichum candidum. Archiv für Mikrobiologie 79, 263-273.

STRUNK, C. (1969). Licht- und elektronenmikroskopische Untersuchungen an jungen Protoplasten von Polystictus versicolor. Zeitschrift für allgemeine Mikrobiologie 9, 49-60.

Villanueva, J. R. \& Garcia Acha, I. (197I). Production and use of fungal protoplasts. In Methods in Microbiology, vol. 4, pp. 665-718. Edited by C. Booth. New York: Academic Press. 
DE VRIES, O. M. H. \& Wessels, J. G. H. (1972). Release of protoplasts from Schizophyllum commune by a lytic enzyme preparation from Trichoderma viride. Journal of General Microbiology 73, 13-22.

Wessels, J. G. H. (1965). Morphogenesis and biochemical processes in Schizophyllum commune. Fr. Wentia I3, I-II3.

Wessels, J. G. H. (1969). A $\beta$-I,6-glucanohydrolase involved in hydrolysis of cell-wall glucan in Schizophyllum commune. Biochimica et biophysica acta $\mathbf{1 7 8}$, I9I-I93.

Wessels, J. G. H., Kreger, D. R., Marchant, R., Regensburg, B. A. \& de Vries, O. M. H. (I972). Chemical and morphological characterization of the hyphal wall surface of the basidiomycete Schizophyllum commune. Biochimica et biophysica acta 273, 346-358. 